\title{
ANALISIS FAKTOR-FAKTOR YANG MEMPENGARUHI KUALITAS PELAYANAN TERHADAP KEPUASAN PELANGGAN PT. PELINDO II CABANG BENGKULU.
}

\author{
Syopian \\ Program Studi Manajemen \\ Fakultas Ekonomi Universitas PROF. DR. Hazairin, SH Bengkulu
}

\begin{abstract}
This research was conducted to find out and measure the variable quality of service (tangible, reliability, responsiveness, assurance, emphaty) significantly influence customer satisfaction PT. Pelindo II Cab. Bengkulu. The method of data collection is carried out by observation and questionnaire methods. The results showed the dimensions of Tangible service quality (X1), Reability (X2), Responsiveness (X3), Assurance (X4) and Emphaty (X5), together had a positive effect. Regression equation $\mathrm{Y}=4.721+0.207 \mathrm{X} 1+0.222 \mathrm{X} 2+0.182 \mathrm{X} 3+0.350 \mathrm{X} 4-0.394 \mathrm{X} 5$. F test amounted to 27,221 while $F$ table 2,31, means F-count> F-table $(27,221>2,31)$. The results show the quality of tangible, reability, responsiveness, assurance, and empathy services together have a positive and significant effect on the variable customer satisfaction. The $\mathrm{t}$ test is known to show the Tangibles Variable $\mathrm{t}$ count of 3.384. This value is greater than $t$ table $(3,384>1,986)$. Reliability Variables $t$ count at 3.058 this value is greater than $t$ table (3.058> 1.986). The Responsiveness variable $t$ counts for 1,992 this value is greater than t table (1992>1,986). Variable Assurance $t$ count at 6,576, this value is greater than $t$ table $(6,576>1,986)$. Empathy variable has a value of $t$ count of $-7,259$. This value is greater than $t$ table $(-7.259<1,986)$
\end{abstract}

Keywords: Customer Satisfaction, tangible, reliability, responsiveness, assurance, empathy

\section{PENDAHULUAN}

Kepuasan yang diperoleh pelanggan tidak tumbuh dengan sendirinya melainkan perlu diciptakan. Kepuasan pelanggan ini biasanya berkaitan erat dengan kepentingan dalam memperoleh layanan yang baik yakni menyangkut kebutuhan dan keinginan atau harapan pelanggan terhadap perusahaan, oleh karena itu untuk memberikan kepuasan, perusahaan harus memberikan layanan yang maksimal kepada pelanggannya. Kepuasan pelanggan diperoleh tidak cukup hanya dari kecepatan, ketepatan, dan keamanan serta keramahan atau sikap para personil atau petugas perusahaan pemberi layanan dalam memperlakukan pelanggan sehingga pelanggan dapat merasa dirinya dihargai dengan perasaan yang aman, wajar dan baik dengan begitu diharapkan akan memacu timbulnya kepercayaan dan dukungan yang positif terhadap perusahaan.

Kepercayaan dan dukungan pelanggan sebagai bagian dari pelanggan eksternal perusahaan secara langsung maupun tidak langsung dapat mempengaruhi citra perusahaan. Oleh karena itu hal yang paling penting bagi perusahaan untuk selalu 


\section{CREATIVE RESEARCH MANAGEMENT JOURNAL-CRMJ Juli}

menciptakan dan mempertahankan kepercayaan, loyalitas dan dukungan dari pihak pelanggan adalah dengan memberikan kepuasan pelayanan yang baik untuk pelanggan tersebut. Sebab tingkat kepuasan pelanggan merupakan indikator atau kata kunci dalam mencapai suatu keberhasilan tugas atau majunya dari suatu perusahaan tersebut.

Dengan diterapkannya perdagangan bebas di Indonesia maka arus barang dari atau ke Indonesia akan meningkat tajam. Oleh karena itu sarana transportasi yang efisien dan efektif sangat penting dalam rangka menciptakan biaya operasional angkutan pada tingkat minimum. Salah satu sarana transportasi yang sangat murah untuk menunjang kegiatan ekspor dan impor adalah transportasi melalui laut. Dengan demikian dibutuhkan pelabuhan sebagai tempat penghubung antara moda laut dengan moda darat. Pelabuhan sebagai penyedia jasa pelayanan jasa kepelabuhan diharapkan mampu memberikan pelayanan yang prima, sehingga eksportir maupun importir tidak dirugikan dengan peningkatan biaya akibat pelayanan yang tidak optimal.

Saat ini jumlah pelabuhan di Indonesia sebanyak 2060 buah, terdiri dari pelabuhan khusus dan umum. Pelabuhan umum sendiri dapat dibedakan menjadi pelabuhan yang diusahakan dan pelabuhan yang tidak diusahakan. Berdasarkan informasi dari Dirjen Perhubungan Laut (2000, III.2.6), jumlah pelabuhan yang diusahakan di Indonesia sebanyak 111 pelabuhan di bawah manajemen PT. Pelabuhan Indonesia I s/d IV (Persero). Bagi pelabuhan - pelabuhan ini, pengelolaannya harus didasarkan atas prinsip-prinsip ekonomi perusahaan dan dengan profesionalisme yang tinggi. Selain berfungsi sebagai public utilities atau mengemban misi kepentingan umum.

Pelabuhan umum yang diusahakan juga ditugasi oleh pemerintah untuk memperoleh laba yang memadai, demi menjaga kelangsungan penyelenggaraan layanan jasa pelabuhan di Indonesia. Jasa kepelabuhanan meliputi pelayanan kapal (Labuh, Tambat, Pandu, Tunda dan Air) dan pelayanan barang (Jasa dermaga dan Jasa penumpukan). Jasa kepelabuhanan memiliki peranan masing-masing dan memiliki keterkaitan satu dengan lainnya demi menunjang kelancaran aktifitas kapal dalam kegiatannya mendistribusikan barang. PT. Pelabuhan Indonesia (Persero) sebagai penyedia jasa kepelabuhanan dituntut oleh konsumen untuk dapat memberikan pelayanan yang efektif dan efisien, sehingga kegiatan pendistribusian barang tidak terhambat yang berdampak terhadap tingginya biaya kepelabuhanan dan menyebabkan kenaikan harga barang itu sendiri.

Pelabuhan Bengkulu (Pulau Baai) yang berada di bawah manajemen PT. Pelabuhan Indonesia II (Persero), merupakan pelabuhan yang penting dan strategis bagi sistem transportasi laut maupun perkembangan perekonomian Provinsi Bengkulu khususnya dan Indonesia pada umumnya. Tantangan dan ancaman yang dihadapinya sangat besar mengingat persaingan antar pelabuhan Indonesia di Indonesia maupun persaingan dari pelabuhan-pelabuhan luar negeri yang dewasa ini meningkat. Bengkulu yang dahulu disebut Bencoolen merupakan kota pelabuhan tua Bencoolen yang dijadikan kota pendudukan dan perdagangan oleh inggris pada abad ke 18 dan 19 . Pelabuhan Bengkulu (Pulau Baai) berada sekitar $20 \mathrm{~km}$ dari pusat kota Bengkulu dan memiliki hinterlan yang cukup luas dengan potensi pertambangan, perkebunan dan 


\section{CREATIVE RESEARCH MANAGEMENT JOURNAL-CRMJ Juli}

kehutanan yang dapat dimanfaatkan untuk pengembangan agrobisnis, pertambangan dan industri.

Kendala utama dalam pengoperasian pelabuhan ini adalah tingkat sedimentasi alur dan kolam yang relatif cepat, sehingga memerlukan perawatan pengerukan secara rutin dengan biaya yang relatif besar. Untuk menampung kegiatan pelayanan barang curah kering, pelabuhan ini dilengkapi dengan 2 buah conveyor belt pemuatan batu bara untuk percepatan pelaksanaan bongkar muat hasil tambang tersebut. Manajemen Pelabuhan Indonesia (Pelindo) II Cabang Bengkulu mengimplementasikan sistem jasa kepelabuhanan yang beroperasi selama 24 jam sehari dan tujuh hari seminggu (24/7) di Pelabuhan Pulau Baai, Bengkulu. Sistem baru itu merupakan bagian dari strategi untuk meningkatkan efisiensi pelabuhan.

Berbekal sistem yang diberlakukan pada 2013 ini, pelabuhan juga dapat melayani kebutuhan pelanggan setiap saat. "Pelabuhan Pulau Baai, sebagai salah satu infrastruktur utama penunjang ekonomi di wilayah Bengkulu, diharapkan dapat menyokong pemerataan ekonomi nasional yang menjadi cita-cita Indonesia Port Corporation (IPC) dan pemerintah Indonesia," kata Direktur Komersial dan Usaha PT Pelabuhan Indonesia II Saptono R Irianto dalam siaran pers tertulis. Saptono juga mengungkapkan kalau Pelindo terus melakukan pembenahan fasilitas, penambahan dermaga dan peralatan bongkar muat di pelabuhan.

Peningkatan kebutuhan jasa pelabuhan di Provinsi Bengkulu dapat menjadi indikator pertumbuhan ekonomi di provinsi tersebut. Data di Pelindo menunjukkan adanya pertumbuhan rata-rata arus barang nonpeti kemas di Pulau Baai sebesar 25\% dalam waktu lima tahun terakhir. Peningkatan yang signifikan tersebut merupakan hasil investasi yang dilakukan untuk membenahi fasilitas di Pelabuhan Pulau Baai. Pada 2011, Pelindo II sebagai operator pelabuhan melakukan pengeruk alur hingga 12MLWS. Pengerukan itu memungkinkan kapal-kapal peti kemas bersandar di pelabuhan sehingga menumbuhkan kembali pasar peti kemas yang sempat terhenti pada 2005-2011. Dalam lima tahun terakhir, jumlah kapal yang bersandar di Pelabuhan Pulau Baai naik sebesar 18\%. Di samping jumlah kapal, ukuran kapal yang berlabuh di Pelabuhan Pulau Baai pun lebih besar dari pada sebelumnya. Hal itu terlihat dari Gross Tonnage (GT) kapal yang tumbuhn 34\% sejak 2007.

Sejalan dengan peningkatan jumlah dan kapasitas kapal-kapal yang bersandar, Pelabuhan Pulau Baai mengalami peningkatan trafik arus barang yang signifikan. Pada 2010 realisasi arus barang berdasarkan perdagangan mencapai 2.4 juta ton. Sedangkan arus barang berdasarkan distribusi 2.7 juta ton. Jumlah tersebut meningkat hampir dua kali lipat pada 2012 menjadi 4,6 juta ton. Pelabuhan Pulau Baai yang sebelumnya selalu mengalami kerugian, pada 2012 berhasil mencetak rekor pendapatan sebesar Rp100 miliar. (http://www.indonesiaport.co.id/news/, $19.30:$ 25/06/2013). Faktor-faktor yang menjadi dasar pertimbangan masyarakat untuk memilih jasa pelabuhan, baik secara langsung maupun tidak langsung dapat membentuk loyalitas pada diri masyarakat akan jasa yang dijadikan sebagai pilihan yang dipercayainya terutama pada sektor perekonomian, di mana para pelaku ekonomi lebih leluasa dalam menjalankan proses kegiatan ekonominya untuk menunjang kelangsungan hidup. 


\section{CREATIVE RESEARCH MANAGEMENT JOURNAL-CRMJ Juli}

Faktor-faktor yang mempengaruhi dimensi kualitas jasa, terdiri dari : (1) Tangible (wujud nyata) seperti jumlah personil pandu, (2) Reliability (keandalan) seperti keahlian (3) Responsiveness (daya tanggap) seperti kecepatan pelayanan, (4) Assurance (jaminan) seperti keselamatan dan (5) Empathy (Perhatian) seperti pemahaman. Sedangkan kepuasan pelanggan adalah evaluasi purna beli dimana alternatif yang dipilih sekurang-kurangnya memberikan hasil sama atau melampuai harapan, sedangkan ketidakpuasan timbul apabila hasil yang diperoleh tidak memenuhi harapan (Tjiptono, 2000:146).

\section{TINJAUAN PUSTAKA}

\section{Pemasaran dan Manajemen Pemasaran}

Aspek terpenting dalam dunia bisnis adalah pemasaran kepentingan ini sangat mendasar, karena pemasaran adalah salah satu proses yang dapat dilakukan oleh suatu usaha khususnya yang bertujuan untuk mencapai keuntungan melalui sistem pemasaran atau dari pasar yang ada. Karena sistem pemasaran harus dapat dikelola dengan baik, maka perlu adanya keputusan yang tepat sebelum menentukan suatu kebijakan yang berkaitan dengan pasar itu sendiri dan dalam usaha pemasaran antar pasar dalam menarik konsumen maupun pelanggan, di dalam hal ini konsumen jasa PT. Pelindo II Cabang Bengkulu termasuk pelanggan, maka perusahaan berusaha menciptakan minat pelanggan hal ini secara jelas digariskan dalam ruang lingkup pemasaran antara lain mencakup kegiatan promosi, distribusi, penetapan harga penjualan dan pembelian akan tetapi dalam hal ini PT. Pelindo II Cabang Bengkulu yang menawarkan jasa pelayanan yang lebih baik.

Pengertian umum pemasaran menurut Tjiptono (2002:7) yaitu Suatu proses sosial dan manajerial dimana individu atau kelompok mendapatkan apa yang mereka butuhkan dan inginkan melalui penciptaan, pewarnaan, dan pertukaran segala sesuatu yang bernilai dengan orang atau kelompok lain. Selanjutnya Kotler, (2002:9) mendefinisikan pemasaran sebagai suatu proses sosial yang didalamnya individu dan kelompok mendapatkan apa yang mereka butuhkan dan inginkan dengan menciptakan, menawarkan, dan secara bebas mempertukarkan produk yang bernilai dengan pihak lain.

Definisi tersebut memberikan pemahaman pemasaran sebagai suatu proses pemenuhan kebutuhan yang dimulai dari timbulnya kebutuhan dan permintaan yang ditanggapi dengan memperhatikan suatu produk untuk memenuhi permintaan tersebut dimana dalam produk tersebut tercakup di dalamnya biaya dan unsur kepuasan yang menyebabkan timbulnya transaksi di pasar antara pemasar dan konsumen adapun produk yang ditawarkan selalu mempunyai nilai lebih di mata konsumen. Pada sisi lain Swastha (2000: 6) memandang pemasaran sebagai suatu usaha untuk memuaskan kebutuhan pembeli dan penjual melalui proses pertukaran. Dari definisi ini tersirat makna bahwa pemasaran merupakan suatu proses yang memberikan jawaban atas kebutuhan dan keinginan konsumen, atau dengan kata lain dapat pula dikatakan bahwa kegiatan pemasaran diciptakan oleh pembeli dan penjual dimana kedua belah pihak sama-sama ingin mencari kepuasan dalam hal ini, pembeli berusaha memenuhi kebutuhannya, sedangkan penjual berusaha mendapatkan laba, selanjutnya kedua 


\section{CREATIVE RESEARCH MANAGEMENT JOURNAL-CRMJ Juli}

macam kepentingan ini dapat dipertemukan dengan cara mengadakan pertukaran yang saling menguntungan.

Kepuasan pelanggan adalah merupakan salah satu tujuan dari pemasaran yang diakibatkan oleh karena adanya pertukaran, maka dunia usaha yang menciptakan atau memproduksi barang dan jasa yang akan dikonsumsi oleh masyarakat atau konsumen perlu memperhatikan beberapa aspek tentang sistem pemasaran yang akan di lakukannya sehingga benar-benar produk yang dihasilkan itu dapat memberikan nilai atau manfaat dan kepuasaan dari konsumen. Untuk melangkah pada proses tersebut, maka dunia usaha perlu untuk memikirkan terlebih dahulu tentang kebutuhan, keinginan dan permintaan masyarakat atau konsumen, sehingga dalam sistem pemasaran yang dilakukan produk yang akan dilempar kepada konsumen tersebut tidak mengalami kesulitan.

Dari penjelasan yang telah diuraikan di atas, maka dapat dikatakan bahwa sebelum melakukan kegiatan pemasaran terlebih dahulu perlu dipertimbangkan tentang kebutuhan, keinginan dan permintaan konsumen, sehingga dalam kegiatan pemasaran dapat berjalan dengan baik dan apa yang diinginkan oleh pelanggan dapat dipenuhi oleh produsen yang menciptakan barang maupun jasa.

\section{Kualitas Jasa}

Kualitas yang dihasilkan oleh barang atau jasa sangat erat kaitannya dengan kepuasan konsumen. Kualitas dapat memberikan dorongan kepada pelanggan untuk menjalin hubungan yang kuat dengan perusahaan. Dalam jangka panjang hubungan yang terjalin dapat memungkinkan perusahaan untuk memahami dengan seksama harapan pelanggan serta kebutuhan mereka. Perusahaan dapat meningkatkan kepuasan pelanggan dengan cara memaksimumkan pelayanan yang menyenangkan dan menghilangkan pelayanan yang membosankan serta menjengkelkan. Sebab harus disadari kualitas serta harga yang murah sekalipun jika tidak diikuti dengan pelayanan yang baik, akan menyebabkan pelanggan berpaling pada produk atau jasa yang sejenis yang kira-kira dapat memberikan kepuasan sama yang ditawarkan oleh pesaing.

Kualitas jasa menurut Wyckop (Tjiptono, 2000:54) adalah tingkat keunggulan yang diharapkan dan pengendalian atas tingkat keunggulan tersebut untuk memenuhi keinginan pelanggan. Kualitas seringkali disamakan dengan mutu. Mutu sama dengan kualitas dimana mutu adalah keseluruhan ciri dari atribut produk atau pelayanan yang berpengaruh pada kemampuannya untuk memuaskan kebutuhan yang dinyatakan atau yang tersirat.

Sehingga dari definisi di atas, maka dapat ditarik sebuah kesimpulan bahwa perusahaan tidak dapat mengklaim diri telah memberikan kualitas terbaik lewat produk atau jasa pada pelanggan, sebab yang dapat mengambil kesimpulan baik dan tidaknya kinerja sebuah produk atau jasa yang dihasilkan oleh perusahaan hanyalah konsumen dan pelanggan. Tidak berlebihan jika sering dikatakan bahwa konsumen adalah raja. Selain itu kesimpulan yang juga dapat diambil, bahwa perusahaan harus dapat mengendalikan kinerja pelayanannya agar sesuai dengan ekspektasi pelanggan. Apabila jasa yang diterima atau yang dirasakan sesuai dengan yang diharapkan maka dapat dipastikan cenderung untuk mendekati kepuasan yang diharapkan oleh pelanggan. 
Sebaliknya jika jasa yang diterima lebih rendah dari yang diharapkan, maka secara otomatis telah memberikan nilai yang buruk dalam persepsi konsumen. Baik dan tidaknya kualitas jasa atau produk yang ditawarkan tergantung pada kemampuan pihak fasilitator (penyedia) dalam memenuhi harapan pelanggan.

\section{Pengukuran Kualitas Jasa}

Kualitas jasa dipengaruhi dua variabel, menurut Rangkuti (2002: 21) kedua variabel tersebut yaitu jasa yang dirasakan (perceived service) dan jasa yang diharapkan (expected service). Pengukuran kualitas jasa lebih sulit dibandingkan dengan mengukur kualitas produk nyata, sebab atribut yang melekat pada jasa tidak mudah untuk diidentifikasi. Menurut Tjiptono (2000: 97) langkah-langkah yang harus diambil dalam mengukur kualitas jasa adalah:

1. Spesifikasi determinan kualitas jasa. Langkah ini menyangkut variabel yang digunakan untuk mengukur kualitas jasa

2. Perangkat standar kualitas jasa yang bisa diukur. Kualitas jasa yang dimaksud adalah menyangkut tentang standar atau instrument kualitas jasa yang bisa digunakan untuk mengukur variabel.

\section{Faktor-Faktor yang Menentukan Kualitas Jasa}

Sebuah perusahaan jasa sebisa mungkin dapat memberikan jasa yang berkualitas tinggi secara konsisten dan kontinyu dibandingkan dengan pesaing, dalam rangka memenuhi harapan pelanggan. Usaha jasa terbilang cukup rumit dan sangat kompleks dari pada barang yang mempunyai wujud konkrit, sehingga menyulitkan seseorang untuk mengidentifikasinya dalam waktu yang singkat. Akan tetapi beberapa pakar di bidang pemasaran mencoba melakukan studi atau mencari pendekatan tentang dimensi atau faktor utama yang menentukan kualitas jasa. Menurut Parasuraman, Zeithamal \& Bery (Rangkuti, 2002: 29), bahwa untuk dapat menentukan standar kualitas jasa dapat dilihat dari dimensi atau kriteria berikut:

a. Reliability (keandalan)

b. Responsiveness (ketanggapan)

c. Competence (kemampuan)

d. Acces (mudah diperoleh)

e. Courtesy (keramahan)

f. Comunication (komunikasi)

g. Credibility (dapat dipercaya)

h. Security (keamanan)

i. Understanding (knowing the costumer) (memahami pelanggan)

j. Tangibles (bukti nyata yang kasat mata)

Kesepuluh dimensi tersebut di atas dapat dikonversi ke dalam lima dimensi, Rangkuti, (2002:29) mengkonversi dari kesepuluh dimensi kualitas jasa sebagai berikut:

1. Tangibles (berwujud) yaitu, penampilan fasilitas fisik, peralatan, personel dan media komunikasi

2. Reliability (keandalan) yaitu, kemampuan untuk melaksanakan jasa yang dijanjikan dengan tepat dan terpercaya. 


\section{CREATIVE RESEARCH MANAGEMENT JOURNAL-CRMJ Juli}

3. Responsiveness (ketanggapan) yaitu, kemampuan untuk membantu pelanggan dalam memberikan jasa dengan cepat dan tanggap.

4. Assurance (keyakinan atau jaminan) yaitu, pengetahuan dan kesopanan karyawan serta kemampuan mereka untuk menimbulkan kepercayaan dan keyakinan.

5. Emphaty (empati) yaitu, merupakan syarat untuk peduli, memberikan perhatian pribadi pada pelanggan.

\section{Pengertian Pelayanan}

Bagi perusahaan yang bergerak dalam bidang manapun pelayanan menjadi sangat berarti dan perlu disadari oleh seorang manajer oleh karena itu dalam usaha bisnis di kenal suatu ungkapan yang terkenal yaitu pembeli adalah raja, yang artinya kita harus melakukan pelayanan sebaik mungkin seakan-akan kita melayani seorang raja. Pelayanan merupakan bentuk pemberian layanan yang diberikan oleh produsen baik terhadap pengguna barang diproduksi maupun jasa yang ditawarkan. Hermawan Kartajaya dkk. (2003: 47) mendefinisikan pelayanan sebagai paradigma perusahaan untuk menciptakan sebuah nilai abadi bagi pelanggan melalui produk dan pelayanan.

Hal yang paling penting dalam suatu usaha adalah kualitas pelayanan yang diberikan, konsumen akan merasa puas jika pelayanan yang diberikan sangat baik. Karena keberhasilan suatu produk sangat ditentukan pula baik tidaknya pelayanan yang diberikan perusahaan dalam memasarkan produknya baik itu pelayanan sewaktu penawaran produk, pelayanan keramahan wiraniaga, pelayanan satpam, pelayanan kasir, pelayanan pengaturan parkir, hingga pelayanan terhadap kondisi produk pasca pembelian. Apabila pelayanan yang ditawarkan perusahaan sesuai dengan keinginan konsumen maka produk/jasa yang ditawarkan akan dibeli. Sedangkan bila terjadi pelayanan yang tidak sesuai dengan keinginan konsumen maka dapat di pastikan produk/jasa tersebut kurang diminati konsumen.

\section{Kualitas Pelayanan}

Bagi perusahaan yang bergerak di bidang jasa, kualitas pelayanan merupakan faktor yang sangat penting. Karena dalam memasarkan produk jasa, interaksi antara produsen dan konsumen terjadi secara langsung. Aplikasi kualitas pelayanan sebagai sifat dari penampilan produk atau kinerja merupakan salah satu bagian utama dari strategi perusahaan dalam meraih keunggulan yang berkesinambungan. Baik sebagai pemimpin pasar atau sebagai strategi untuk terus berkembang. Menurut Tjiptono (2000: 81) bahwa kualitas pelayanan adalah merupakan kondisi dinamis yang berhubungan dengan produk jasa, dan manusia proses dan lingkungan yang memenuhi atau melebihi pelanggan. Sedangkan menurut Parasuraman, Berry dan Zenthaml (dalam Lupiyoadi,2006: 181). Keberhasilan perusahaan dalam memberikan pelayanan yang berkualitas dapat ditentukan dengan pendekatan service quality.

Pelayanan yang berkualitas dan memenuhi kepuasan konsumen terdiri dari tiga komponen dasar yang harus dipahami bagi setiap perusahaan yaitu:

a. Proses sebelum penjualan

Pada tahap ini perusahaan mempunyai kesempatan untuk membentuk hubungan dengan konsumen. Hal ini dapat dilakukan dengan menginformasikan produk 


\section{CREATIVE RESEARCH MANAGEMENT JOURNAL-CRMJ Juli}

pada konsumen dan menciptakan kepercayaan pada konsumen atas produk yang ditawarkan.

b. Proses selama transaksi

Pada fase ini perusahaan harus tetap menjaga kualitas pelayanan. Agar konsumen tetap menjadi pelanggan setia. Komunikasi pada fase ini sangat penting. Sebab pada fase ini konsumen membutuhkan informasi lebih banyak lagi akan produk yang dibeli. Jika pihak perusahaan tidak memahami tentang produk yang ditawarkan bisa saja konsumen beralih pada perusahaan lain.

c. Proses sesudah penjualan

Pada fase ini perusahaan diharapkan mendengar atau menanggapi keluhan dari pihak konsumen atas produk yang telah dibeli.

Produk jasa atau pelayanan lebih kompleks dibandingkan dengan barang. Hal tersebut disebabkan karena dimensi kualitas pelayanan jasa lebih sulit diidentifikasi. Tetapi beberapa pakar pemasaran telah menemukan dimensi atau faktor utama yang menentukan kualitas pelayanan jasa. melalui penelitian yang dilakukan.

\section{Kepuasan Pelanggan}

Memiliki konsumen yang loyal adalah tujuan akhir dari semua perusahaan. Tetapi kebanyakan dari perusahaan tidak mengetahui bahwa loyalitas konsumen dibentuk melalui beberapa tahapan, dimulai dari mencari calon konsumen potensial sampai dengan pembentukan advocate customer yang akan membawa keuntungan bagi perusahaan. Sebelum membahas lebih jauh mengenai hal-hal apa saja yang perlu dilakukan untuk membentuk loyalitas, perlu diketahui definisi dari loyalitas di bawah ini. Kepuasan pelanggan adalah evaluasi purna beli dimana alternatif yang dipilih sekurang-kurangnya memberikan hasil sama atau melampaui harapan, sedangkan ketidakpuasan timbul apabila hasil yang diperoleh tidak memenuhi harapan (Tjiptono,2000:146).

Melalui komunikasi, baik antar pelanggan maupun dengan supplier akan menjadikan harapan bagi pelanggan terhadap kualitas produk yang akan dibelinya. Pemahaman terhadap harapan-harapan pelanggan oleh supplier merupakan input untuk melakukan perbaikan dan peningkatan kualitas produk, baik barang maupun jasa. Pelanggan akan membandingkan dengan produk jasa lainnya. Bilamana harapanharapannya terpenuhi, maka akan menjadikannya pelanggan loyal, puas terhadap produk barang atau jasa yang dibelinya. Sebaliknya, bilamana tidak puas, supplier akan ditinggalkan oleh pelanggan. Kunci keputusan pelanggan berkaitan dengan kepuasan terhadap penilaian produk barang dan jasa. Kerangka kepuasan pelanggan tersebut terletak pada kemampuan supplier dalam memahami kebutuhan, keinginan dan harapan pelanggan sehingga penyampaian produk, baik barang maupun jasa oleh supplier sesuai dengan harapan pelanggan. Selain faktor-faktor tersebut di atas, dimensi waktu juga mempengaruhi tanggapan persepsi pelanggan terhadap kualitas produk, baik barang maupun jasa. Jadi, tingkat kepuasan adalah fungsi dari perbedaan antara kinerja yang di rasakan dengan harapan.

Untuk dapat menjadi pelanggan yang loyal, seorang pelanggan harus melalui beberapa tahapan. Proses ini berlangsung lama dengan penekanan dan perhatian yang 
berbeda untuk masing-masing tahap karena setiap tahap mempunyai kebutuhan yang berbeda. Dengan memperhatikan masing-masing tahapan dan memenuhi kebutuhan dalam setiap tahap tersebut, perusahaan memiliki peluang yang lebih besar untuk membentuk calon pembeli menjadi pelanggan loyal dan klien perusahaan. Menurut Tjiptono (2000: 24) loyalitas pelanggan adalah: "Suatu hubungan antara perusahaan dan pelanggan di mana terciptanya suatu kepuasan sehingga memberikan dasar yang baik untuk melakukan suatu pembelian kembali terhadap barang yang sama dan membentuk suatu rekomendasi dari mulut ke mulut".

Dapat dikatan loyalitas merupakan kombinasi dari fungsi psikologis dan perilaku seorang konsumen yang membuatnya setia pada produk atau jasa tertentu yang dijual oleh sebuah perusahaan atau merupakan cakrawala pemikiran bahwa kesetian pelanggan merupakan hasil dari perilaku dan proses psikologis seseorang dan pada hakekatnya loyalitas pelanggan dapat diibaratkan perkawinan antara perusahaan dan publik (terutama pelanggan inti). Dapat pula dikatakan bahwa loyalitas (customer loyalty) sebagai suatu komitmen untuk bertahan secara mendalam dengan melakukan pembelian ulang atau berlangganan kembali dengan produk atau jasa yang terpilih secara konsisten dimasa yang akan datang meskipun pengaruh situasi dan usaha-usaha pemasaran mempunyai potensi untuk menyebabkan perubahan perilaku. Karena itu dapat dikatakan bahwa loyal mempunyai fanatisme yang relatif permanen dalam jangka panjang terhadap suatu barang/jasa pada perusahaan yang menjadi pilihannya, tidak ingin beralih pada barang /jasa yang lain, bahkan ikut mempengaruhi pihak lain untuk ikut menggunakan barang/jasa tersebut.

\section{Kerangka Pemikiran}

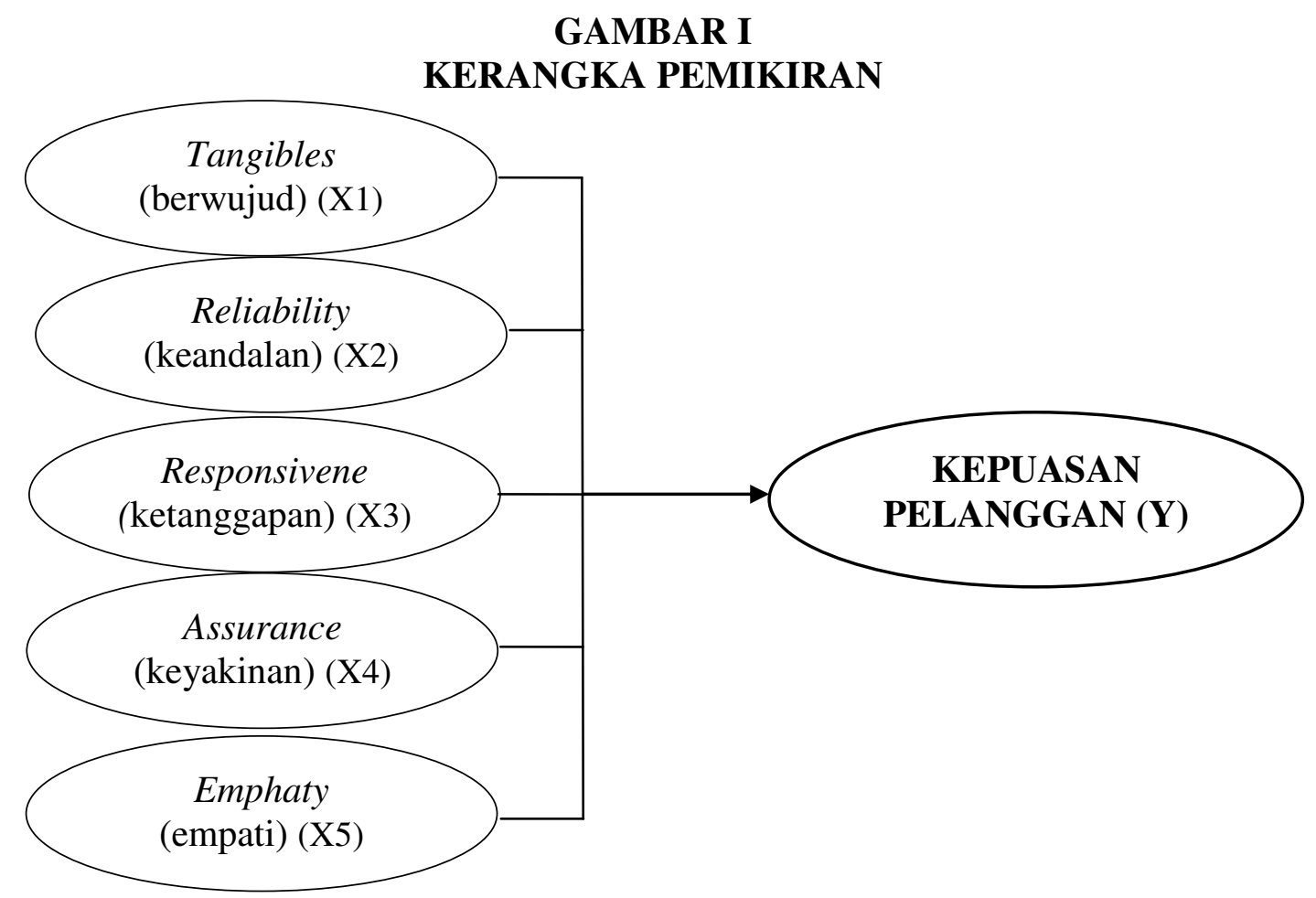


Dari gambar diatas, dapat dilihat bahwa Tangibles (berwujud) (X1), Reliability (keandalan) (X2), Responsivene (ketanggapan) (X3), Assurance (keyakinan) (X4) dan Emphaty (empati) (X5) berpengaruh terhadap kepuasan pelanggan ( Y ).

\section{HASIL PENELITIAN DAN PEMBAHASAN \\ Hasil Penelitian \\ Karakteristik Responden}

Dalam penelitian ini, tujuan yang ingin dicapai oleh PT. Pelindo II Cabang Bengkulu adalah untuk melihat sejauh mana kualitas layanan jasa yang diberikan. Untuk mengimplementasikan hal tersebut maka dilakukan penyebaran kuesioner kepada responden yang terlibat langsung dalam pengisian keusioner. Pelaksanaan penelitian ini, ditetapkan sebesar 100 responden, dimana dari 100 kuesioner yang dibagikan kepada responden, semua kuesioner telah dikembalikan dan semuanya dapat diolah lebih lanjut. Oleh karena itulah akan disajikan dekskripsi karakteristik responden yaitu sebagai berikut :

\section{Jenis Kelamin}

Dekskripsi karakteristik responden menurut jenis kelamin (gender), yaitu pengelompokan responden menurut laki-laki dan perempuan. Untuk mengetahui tingkat proporsi jenis kelamin laki-laki dan perempuan, dapat disajikan melalui tabel II yaitu sebagai berikut :

TABEL II

JENIS KELAMIN RESPONDEN

\begin{tabular}{|l|c|c|}
\hline \multicolumn{1}{|c|}{ Jenis Kelamin } & Jumlah Responden (Orang) & Persentase (\%) \\
\hline Laki-Laki & 68 & 68,0 \\
\hline Perempuan & 32 & 32,0 \\
\hline JUMLAH & $\mathbf{1 0 0}$ & $\mathbf{1 0 0 , 0}$ \\
\hline
\end{tabular}

Sumber: Data primer diolah, 2013

Berdasarkan tabel II yaitu proporsi pengelompokan responden yang menunjukkan bahwa tingkat proporsi persentase pengelompokan yang terbesar adalah lebih banyak didominasi oleh laki-laki yaitu sebesar 68 orang (68\%). Hal ini dapat dikatakan bahwa sebagian besar pengguna jasa PT. Pelindo II Cabang Bengkulu adalah lebih banyak didominasi oleh laki-laki jika dibandingkan dengan nasabah yang berjenis kelamin perempuan.

\section{Dekskripsi Pendidikan Responden}

Dekskripsi pendidikan responden menjelaskan uraian tingkat pendidikan responden, sehingga dalam dekskripsi pendidikan responden maka dapat dikelompokkan yaitu: SD, SMP, SMA, Diploma, Sarjana. Untuk lebih jelasnya akan disajikan proporsi presentase responden menurut tingkat pendidikan yang dapat dilihat melalui tabel berikut ini: 
TABEL III

TINGKAT PENDIDIKAN

\begin{tabular}{|l|c|c|}
\hline Tingkat Pendidikan & Jumlah Responden (Orang) & Persentase (\%) \\
\hline SD & - & - \\
\hline SMP & - & - \\
\hline SMA & 63 & 63,0 \\
\hline DIPLOMA & 5 & 5,0 \\
\hline SARJANA & 32 & 32,0 \\
\hline JUMLAH & $\mathbf{1 0 0}$ & $\mathbf{1 0 0 , 0}$ \\
\hline
\end{tabular}

Sumber: Data primer diolah, 2013

Berdasarkan tabel III yaitu proporsi persentase pengelompokan responden yang menjadi sampel dalam penelitian ini adalah responden yang berpendidikan SMA yaitu sebanyak 63 orang $(63 \%)$. Hal ini menunjukkan bahwa sebagian besar tingkat pendidikan pengguna jasa pada PT. Pelindo II Cabang Bengkulu adalah SMA.

\section{Dekskripsi Responden Menurut Umur}

Adapun dekskripsi responden menurut umur dapat dilihat pada tabel III berikut ini :

TABEL IV

UMUR RESPONDEN

\begin{tabular}{|l|c|c|}
\hline Tingkat Umur Responden & Jumlah Responden (Orang) & Persentase (\%) \\
\hline$<25$ tahun & 19 & 19,0 \\
\hline $26-35$ tahun & 58 & 58,0 \\
\hline $36-35$ tahun & 20 & 20,0 \\
\hline$>45$ tahun & 3 & 3,0 \\
\hline JUMLAH & $\mathbf{1 0 0}$ & $\mathbf{1 0 0 , 0}$ \\
\hline
\end{tabular}

Sumber: Data primer diolah, 2013

Berdasarkan tabel IV yaitu proporsi responden menurut usia yang menunjukkan bahwa sebagian besar responden yang menjadi sampel dalam penelitian ini adalah responden yang berumur 26-35 tahun yaitu sebesar 58 orang. Hal ini menunjukkan bahwa sebagian besar pengguna jasa PT. Pelindo II Cabang Bengkulu adalah berumur 26-35 tahun.

\section{Pembahasan}

\section{Uji Kualitas Data}

\section{Uji Validitas}

Kuesioner merupakan salah satu alat pengumpulan data utama yang digunakan di dalam penelitian ini. Kuesioner ini diharapkan dapat mengungkap presepsi responden mengenai variabel yang diteliti. Olehnya indikator pengukuran yang tertuang dalam bentuk kuesioner tersebut harus mempunyai kemampuan untuk mengukur variabelnya. Kemampuan indikator mengukur variabelnya disebut uji validitas (kesahihan butir). 


\section{CREATIVE RESEARCH MANAGEMENT JOURNAL-CRMJ Juli}

2018

Solimun (2002:70) mengatakan bilamana koefisien korelasi antar skor suatu indikator dengan skor total seluruh indikator adalah positif dan lebih besar 0,3 ( $\mathrm{r} \geq 0,3)$ maka instrumen tersebut dianggap valid. Sedangkan menurut Santoso (2001: 278) bahwa instrumen dapat dikatakan valid manakalah $r_{\text {hitung }}$ yang diperoleh lebih besar dari $r_{\text {tabel. }}$ Dalam penelitian ini di harapan semakin tinggi nilai batas syarat validitas diharapkan dapat memberikan keakuratan kuesioner dalam mengukur presepsi responden sehingga dapat pula memberikan kesimpulan penelitian apa adanya. Hasil uji validitas data dapat di jelaskan dalam tabel IV sebagai berikut :

\section{TABEL V \\ HASIL}

\begin{tabular}{|r|r|r|r|r|}
\hline & $\begin{array}{c}\text { Scale Mean if } \\
\text { Item Deleted }\end{array}$ & $\begin{array}{c}\text { Scale Variance } \\
\text { if Item Deleted }\end{array}$ & $\begin{array}{c}\text { Corrected Item- } \\
\text { Total Correlation }\end{array}$ & $\begin{array}{c}\text { Cronbach's Alpha } \\
\text { if Item Deleted }\end{array}$ \\
\hline X1.1 & 11.9400 & 4.602 & .719 & .813 \\
\hline X1.2 & 12.0000 & 4.747 & .653 & .839 \\
\hline X1.3 & 11.8600 & 4.445 & .731 & .808 \\
\hline X1.4 & 11.9900 & 4.212 & .713 & .816 \\
\hline X2.1 & 11.4200 & 3.781 & .601 & .685 \\
\hline X2.2 & 11.3900 & 3.351 & .589 & .691 \\
\hline X2.3 & 11.2500 & 3.987 & .557 & .709 \\
\hline X2.4 & 11.3900 & 3.816 & .507 & .734 \\
\hline X3.1 & 12.2000 & 2.606 & .422 & .683 \\
\hline X3.2 & 12.2100 & 2.450 & .520 & .626 \\
\hline X3.3 & 12.2700 & 2.260 & .582 & .585 \\
\hline X3.4 & 12.2500 & 2.351 & .452 & .671 \\
\hline X4.1 & 12.0400 & 5.554 & .785 & .857 \\
\hline X4.2 & 11.9700 & 5.504 & .781 & .858 \\
\hline X4.3 & 11.9600 & 5.716 & .755 & .868 \\
\hline X4.4 & 12.1500 & 5.058 & .756 & .871 \\
\hline X5.1 & 11.1100 & 5.937 & .790 & .852 \\
\hline X5.2 & 11.1900 & 4.984 & .785 & .858 \\
\hline X5.3 & 11.1100 & 5.553 & .815 & .840 \\
\hline X5.4 & 11.0800 & 6.418 & .686 & .888 \\
\hline Y.1 & 10.4400 & 3.542 & .511 & .485 \\
\hline Y.2 & 10.6300 & 3.468 & .441 & .493 \\
\hline Y.3 & 10.5100 & 3.384 & .226 & \\
\hline Y.4 & 10.8400 & 3.732 & & .699 \\
\hline S4m & & & \\
\hline
\end{tabular}

Sumber : Data primer diolah, 2013. 
Mengacu dengan pendapat Solimun di atas maka dapat dikatakan bahwa instrumen yang digunakan dalam penelitian ini telah memiliki kesahihan butir, karena nilai korelasi yang diperoleh masing-masing indikator lebih besar $0,3(\mathrm{r} \geq 0,3)$. Kecuali untuk butir pertanyaan Y.4 tidak dapat diikut sertakan untuk dianalisis karena tidak memenuhi syarat $r \geq 0,3$.

\section{Uji Reliabilitas}

Sebagaimana telah dijelaskan di atas bahwa untuk mengumpulkan data dalam penelitian ini digunakan kuesioner. Oleh karena kuesioner yang digunakan adalah kuesioner yang belum terukur tingkat konsistensi pertanyaannya, maka untuk mengukur tingkat konsistensi perlu dilakukan pengujian konsistensi atau yang lazim disebut uji reliabilitas. Malhotra (Solimun, 2002: 71) mengatakan suatu instrumen dikatakan reliabel manakalah memenuhi standar koefisien alpha Cronbach lebih besar dari 0,6 ( $\alpha$ $\geq 0.6$ ). Berdasarkan hasil pengujian reliabilitas keseluruhan variabel penelitian diketahui masing-masing variabel mempunyai alpha Cronbach sebagaimana yang tampak dalam tabel VI berikut:

TABEL VI

HASIL UJI RELIABILITAS

\begin{tabular}{|c|c|c|c|c|}
\hline & $\begin{array}{c}\text { Cronbach's } \\
\text { Alpha }\end{array}$ & r table & $\begin{array}{c}\mathbf{N} \\
\text { of Items }\end{array}$ & Keterangan \\
\hline X1 & .858 & 0,6 & 4 & Reliabel \\
\hline X2 & .761 & 0,6 & 4 & Reliabel \\
\hline X3 & .706 & 0,6 & 4 & Reliabel \\
\hline X4 & .894 & 0,6 & 4 & Reliabel \\
\hline X5 & .892 & 0,6 & 4 & Reliabel \\
\hline Y & .699 & 0,6 & 3 & Reliabel \\
\hline
\end{tabular}

Sumber : Data primer diolah, 2013.

Menurut pendapat Malhotra (Solimun, 2002: 71) bahwa suatu instrumen dikatakan reliabel manakala memenuhi standar koefisien alpha Cronbach lebih besar dari 0,6 $(\alpha \geq 0.6)$ maka dapat dikatakan bahwa angka koefisien reliabilitas yang diperoleh sebagaimana pada tabel VI telah memenuhi syarat reliabilitas, dengan demikian kuesioner yang digunakan dalam penelitian ini cukup handal dalam mengukur persepsi responden terhadap variabel yang diteliti.

\section{Uji Asumsi Klasik}

\section{Uji Multikolinearitas}

Untuk mengetahui gejala multikol dapat dilihat pada nilai VIF (sub bab tiga) apabila < 10 mengindikasikan bahwa dalam model tidak terjadi multikolinieritas, tetapi bila VIF $>10$, mengindikasikan bahwa dalam model terjadi multikolinieritas serius. Dalam penelitian ini nilai VIF yang diperoleh $<10$ (Tabel VII) sehingga dapat dikatakan tidak terjadi multikolinearitas, dengan demikian analisis regresi dapat dilanjutkan. 
TABEL VII

COLLINEARITY STATISTICS

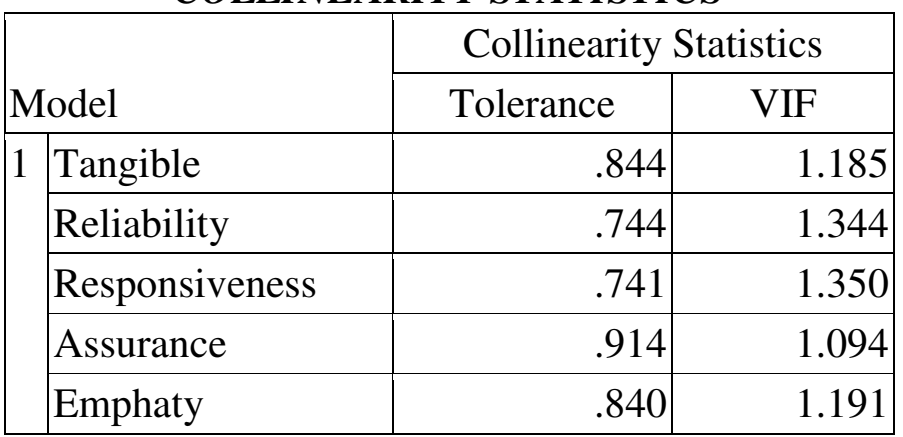

Sumber : Data primer diolah, 2013.

\section{Uji Heterokedastisitas}

Heterokedastisitas menunjukkan adanya gejala kesalahan varians gangguan yang menyebabkan tidak sama probabilitas varian gangguan untuk setiap pengamatan atas seluruh nilai variabel independen. Gejala heterokedastisitas secara sederhananya dapat dilihat dari tabel scatterplot di mana sebaran titik-titik yang terdapat dalam Tabel tersebut tidak membentuk pola yang sistematis. Selain itu dapat pula digunakan korelasi Rank Spearman, dengan cara mengkorelasikan setiap variabel independen dengan varian gangguan (residual). Apabila nilai sig. (2-tailed test) $<0.05$ maka korelasi antara variabel independen dengan nilai residualnya dikatakan signifikan atau dengan kata lain ada gejala hetrokedastisitas. Sebaliknya apabila nilai sig. (2-tailed test) $>0.05$ maka korelasi antara variabel independen dengan residual dikatakan tidak signifikan atau data tersebut homokedastisitas. Dari hasil uji heterokedastisitas dengan menggunakan korelasi Rank Spearman, menunjukan bahwa tidak ada variabel independen yang berkolerasi signifikan terhadap nilai residual. Dengan demikian data yang digunakan adalah data homokedastisitas.

\section{TABEL VIII}

HASIL HETEROKEDASTISITAS

\begin{tabular}{|c|c|c|c|c|c|c|}
\hline \multirow{2}{*}{\multicolumn{2}{|c|}{ Model }} & \multicolumn{2}{|c|}{$\begin{array}{l}\text { Unstandardized } \\
\text { Coefficients }\end{array}$} & \multirow{2}{*}{$\begin{array}{c}\text { Standardized } \\
\text { Coefficients } \\
\text { Beta } \\
\end{array}$} & \multirow[b]{2}{*}{$\mathrm{t}$} & \multirow[b]{2}{*}{ Sig. } \\
\hline & & B & $\begin{array}{l}\text { Std. } \\
\text { Error }\end{array}$ & & & \\
\hline \multirow[t]{6}{*}{1} & (Constant) & .108 & .918 & & .117 & .907 \\
\hline & Tangible & -.026 & .036 & -.078 & -.714 & .477 \\
\hline & Reliability & .034 & .043 & .091 & .781 & .437 \\
\hline & Responsiveness & .057 & .054 & .123 & 1.050 & .297 \\
\hline & Assurance & -.019 & .031 & -.063 & -.593 & .554 \\
\hline & Emphaty & .025 & .032 & .084 & .765 & .446 \\
\hline
\end{tabular}

Sumber : Data primer diolah, 2013. 
Dari output di atas dapat diketahui bahwa nilai signifikansi untuk Tangible sebesar 0,477, Reliability sebesar 0,437, Responsiveness sebesar 0,297, Assurance sebesar 0,554 dan Emphaty sebesar 0,446. Karena signifikansi lebih dari 0,05, maka dapat disimpulkan bahwa pada model regresi tidak ada masalah Heterokedastisitas.

\section{Analisis Korelasi Berganda}

TABEL IX

Model Summary

\begin{tabular}{|c|c|c|c|c|}
\hline Model & $\mathrm{R}$ & R Square & $\begin{array}{c}\text { Adjusted R } \\
\text { Square }\end{array}$ & $\begin{array}{c}\text { Std. Error of } \\
\text { the Estimate }\end{array}$ \\
\hline 1 & $.769^{\mathrm{a}}$ & .591 & .570 & 1.54889 \\
\hline
\end{tabular}

Sumber : Data primer diolah, 2013.

Dari hasil korelasi berganda diperoleh nilai adjusted $\mathrm{R}$ square $\left(\mathrm{R}^{2}\right)$ sebesar 0 , 591 hal ini menunjukkan bahwa variabel bebas $\left(X_{1}, X_{2}, X_{3}, X_{4}\right.$ dan $\left.X 5\right)$ secara bersamasama memberikan kontribusi terhadap variabel terikat Y (Kepuasan Pelanggan) sebesar $59,1 \%$, sedangkan sisanya sebesar 40,9\% dijelaskan oleh variabel - variabel lain diluar tangible, reliability, responsiveness, assurance, dan empathy. Yang mana tangible, reliability, responsiveness, assurance, dan empathy yang berpengaruh cukup terhadap Produktivitas Kerja karena sesuai dengan interpretasi koefisien korelasi nilai $r$ berada di $0,40-0,599$ nilai $\mathrm{R}$ square $\left(\mathrm{R}^{2}\right)$ sebesar 0,591 .

\section{Uji Autokorelasi}

Uji autokorelasi bertujuan untuk mengetahui ada tidaknya korelasi antara data dalam Variabel pengamatan. Apabila terjadi korelasi akan dinamakan ada problem autokorelasi. Autokorelasi muncul karena observasi yang berurutan sepanjang waktu berkaitan satu sama lainnya. Autokorelasi sering terjadi pada sampel dengan data bersifat time series. Pengujian autokorelasi penelitian ini menggunakan uji Durbinwatson (DW test), kriteria pengambilan keputusannya adalah sebagai berikut :

1. Jika d lebih kecil dari dL atau lebih besar dari (4-dL) maka hopotesis nol ditolak, yang berarti terdapat autokorelasi.

2. Jika d terletak antara dU dan (4-dU), maka hipotesis nol diterima, yang berarti tidak ada autokorelasi.

3. Jika d terletak antara dL dan dU atau diantara (4-dU) dan (4-dL), maka tidak menghasilkan kesimpulan yang pasti.

TABEL X

PENGUJIAN ASUMSI AUTOKORELASI

\begin{tabular}{|l|r|r|r|r|r|}
\hline Model & R & R Square & $\begin{array}{c}\text { Adjusted R } \\
\text { Square }\end{array}$ & $\begin{array}{c}\text { Std. Error of } \\
\text { the Estimate }\end{array}$ & $\begin{array}{c}\text { Durbin- } \\
\text { Watson }\end{array}$ \\
\hline 1 & $.769^{\mathrm{a}}$ & .591 & .570 & 1.54889 & 1.902 \\
\hline
\end{tabular}

Sumber : Data primer diolah, 2013. 
Dari hasil output di atas didapat nilai DW yang dihasilkan dari model regresi adalah 1.902. Sedangkan dari tabel DW dengan signifikansi 0,05 dan jumlah data $(\mathrm{n})=$ 100 , seta $\mathrm{k}=5$ ( $\mathrm{k}$ adalah jumlah variabel independen) diperoleh nilai dL sebesar 1,5710 dan dU sebesar 1,7804 (lihat lampiran). Karena nilai DW (1.902) berada pada daerah > dl, maka menghasilkan kesimpulan berarti terdapat autokorelasi.

\section{Hasil Analisis Regresi Berganda}

Berdasarkan data penelitian yang dikumpulkan baik untuk variable terikat (Y) maupun Variabel bebas $(\mathrm{X} 1, \mathrm{X} 2, \mathrm{X} 3, \mathrm{X} 4, \mathrm{X} 5)$ yang diolah dengan menggunakan bantuan program SPSS version 17.0 for windows, maka diperoleh hasil perhitungan regresi linear berganda sebagai berikut :

\section{TABEL XI}

HASIL ANALISA REGRESI BERGANDA

\begin{tabular}{|c|c|c|c|c|c|c|}
\hline & & \multicolumn{2}{|c|}{$\begin{array}{l}\text { Unstandardized } \\
\text { Coefficients }\end{array}$} & \multirow{2}{*}{$\begin{array}{l}\text { Standardized } \\
\text { Coefficients } \\
\text { Beta }\end{array}$} & \multirow[b]{2}{*}{$\mathrm{t}$} & \multirow[b]{2}{*}{ Sig. } \\
\hline \multicolumn{2}{|c|}{ Model } & B & Std. Error & & & \\
\hline \multirow[t]{6}{*}{1} & (Constant) & 4.721 & 1.550 & & 3.045 & .003 \\
\hline & Tangible & .207 & .061 & .243 & 3.384 & .001 \\
\hline & Reliability & .222 & .073 & .234 & 3.058 & .003 \\
\hline & Responsiveness & .182 & .091 & .153 & 1.992 & .049 \\
\hline & Assurance & .350 & .053 & .453 & 6.576 & .000 \\
\hline & Emphaty & -.394 & .054 & -.522 & -7.259 & .000 \\
\hline
\end{tabular}

Sumber : Data primer diolah, 2013.

Pada tabel korelasi menunjukkan suatu hubungan. Pengaruh regresi antara kepuasan pelanggan dengan tangible, kepuasan pelanggan dengan reliability, kepuasan pelanggan dengan responsiveness, kepuasan pelanggan dengan assurance, kepuasan pelanggan dengan empathy.

Dari tabel di atas dapat diperoleh persamaan regresi linear sebagai berikut :

$$
\mathrm{Y}=4.721+0,207 \mathrm{X} 1+0,222 \mathrm{X} 2+0,182 \mathrm{X} 3+0,350 \mathrm{X} 4-0,394 \mathrm{X} 5
$$

Dimana :

a $\quad=4,721$ : Kepuasan pelanggan akan bernilai 4,721dengan asumsi variabel Tangible X1, variabel Assurance X2, variabel Responsiveness X3, variabel Reliability X4, dan variabel Empathy X5 konstan.

0,207X1 : Besarnya koefisien variabel tangible adalah sebesar 0,207 artinya setiap peningkatan kualitas layanan pada variabel tangible secara positif akan mengakibatkan peningkatan kepuasan pelanggan bila variabel lainnya konstan.

0,222X2: Besarnya koefisien variabel reliability adalah sebesar 0,222 artinya setiap peningkatan kualitas layanan pada variabel reliability secara positif akan 
mengakibatkan peningkatan kepuasan pelanggan bila variabel lainnya konstan.

0,182X3 : Besarnya koefisien variabel responsiveness adalah sebesar 0,182 artinya setiap peningkatan kualitas layanan pada variabel responsiveness secara positif akan mengakibatkan peningkatan konstan kepuasan pelanggan bila variabel lainnya konstan.

0,350X4 : Besarnya koefisien variabel assurance adalah sebesar 0,350 artinya setiap peningkatan kualitas layanan pada variabel assurance secara positif akan mengakibatkan peningkatan kepuasan pelanggan bila variabel lainnya konstan.

- 0,394X2 : Besarnya koefisien variabel empaty adalah sebesar - 0,394, artinya setiap penurunan kualitas layanan pada variabel empathy mengakibatkan penurunan kepuasan pelanggan bila variabel lainnya konstan.

\section{Uji Hipotesis}

Uji F

Uji simultan atau uji $\mathrm{F}$ merupakan uji secara bersama - sama untuk menguji signifikan pengaruh variabel kualitas jasa yang terdiri atas Tangible, Assurance, Responsiveness, Reliability, dan Empathy serta bersama-sama terhadap variabel kepuasan pelanggan.

TABEL XII

HASIL Uji F

\begin{tabular}{|ll|l|l|l|l|l|}
\hline Model & & Sum of Squares & df & Mean Square & F & Sig. \\
\hline 1 & Regression & 326.528 & 5 & 65.306 & 27.221 & $.000^{\mathrm{a}}$ \\
& Residual & 225.512 & 94 & 2.399 & & \\
& Total & 552.040 & 99 & & & \\
\hline
\end{tabular}

Sumber : Data primer diolah, 2013.

Berdasarkan hasil regresi dari tabel di atas menunjukkan Fhitung sebesar 27.221 sedangkan hasil Ftabel 2,31. Hal ini berarti Fhitung > Ftabel $(27.221>2,31)$ signifikan. Perhitungan tersebut menunjukkan bahwa kualitas jasa yang terdiri atas tangible, reliability, responsiveness, assurance, dan empathy secara bersama-sama mempunyai pengaruh yang positif dan signifikan terhadap variabel kepuasan pelanggan.

Langkah - langkah untuk melakukan uji F sebagai berikut:

a. Hipotesis

Ho = Kualitas layanan secara simultan tidak mempunyai pengaruh yang signifikan terhadap kepuasan pelanggan.

$\mathrm{H} 1$ = Kualitas layanan secara simultan mempunyai pengaruh yang signifikan kepuasan pelanggan. 
b. Tingkat signifikan

Tingkat signifikan yang digunakan adalah $0,05(\alpha=5 \%)$ dan pada tabel V tingkat signifikan sebesar 0,000 atau sebesar $0 \%$. Artinya bahwa variabel independen berpengaruh terhadap variabel dependen dengan tingkat signifikannya sebesar $0 \%$.

c. Menentukan F tabel

Dengan menggunakan tingkat keyakinan 95\% dengan tingkat kesalahan $\alpha=0,05$, df dapat ditentukan sebagai berikut :

df $1=\mathrm{k}=5$

df $2=\mathrm{n}-\mathrm{k}-1=100-5-1=94$

$\mathrm{n}=$ sampel

$\mathrm{k}=$ variabel bebas

maka Ftabel = 2,31

Ketentuan penerimaan hipotesis yaitu

Ha ditolak bila sig $>0,05$ atau $\mathrm{F}$ hitung $<\mathrm{F}$ tabel

Ha diterima bila sig $\leq 0,05$ atau $\mathrm{F}$ hitung $>\mathrm{F}$ tabel

d. Membandingkan $\mathrm{F}$ hitung $>\mathrm{F}$ tabel

Berdasarkan hasil penelitian yang terdapat pada tabel $\mathrm{V}$ bahwa hasil dari $\mathrm{F}$ hitung yaitu sebesar 27.221 dan Ftabel 2,31, nilai F hitung > F tabel maka dapat dikatakan terdapat pengaruh yang signifikan antara X1, X2, X3, X4, X5 terhadap Y, hal ini menunjukkan bahwa perubahan naik turunya variabel kualitas layanan berpengaruh nyata terhadap tingkat kepuasan pelanggan.

\section{Uji t}

Uji t digunakan untuk menguji signifikansi konstanta dari variabel independent secara sendiri-sendiri. Dengan $t$ tabel sebagai berikut :

$$
\begin{aligned}
\text { Df } & =\mathrm{N}-\mathrm{k}-1 \\
& =100-5-1 \\
& =94
\end{aligned}
$$

Analisis 2 sisi $=0,05 / 2$

$$
=0,025
$$

Berarti batas $\mathrm{x}=0,025 \mathrm{~s} / \mathrm{d} 0,05$

Jadi nilai $\mathrm{t}$ tabel $=1,984$

Ketentuan penerimaan hipotesis yaitu :

Ha ditolak bila sig $>0,05$ atau $t$ hitung $<\mathrm{t}$ tabel

Ha diterima bila sig $\leq 0,05$ atau $\mathrm{t}$ hitung $>\mathrm{t}$ tabel

Berdasarkan tabel VII untuk menguji apakah ada pengaruh masing-masing variabel terhadap kepuasan pelanggan, maka dilakukan uji t (uji parsial) dengan tingkat kepercayaan $95 \%$ dengan Sig t sebesar $0,000<\alpha=0.05$ maka pengujian hipotesis dapat dilakukan sebagai berikut :

a. Variabel Tangibles. Varibel Tangibles memiliki nilai t hitung sebesar 3.384. Nilai ini lebih besar dari t tabel $(3.384>1,984)$. Dengan demikian pengujian menunjukkan Ha diterima atau Ho ditolak. Hasil ini memperlihatkan bahwa variabel Tangibles berpengaruh secara signifikan terhadap kepuasan pelanggan. 
b. Variabel Reliability. Varibel Reliability memiliki nilai t hitung sebesar 3.058. Nilai ini lebih besar dari $\mathrm{t}$ tabel $(3.058>1,984)$. Dengan demikian pengujian menunjukkan $\mathrm{Ha}$ diterima atau Ho ditolak. Hasil ini memperlihatkan bahwa variabel Reliability berpengaruh secara signifikan terhadap kepuasan pelanggan.

c. Variabel Responsiveness. Varibel Responsiveness memiliki nilai t hitung sebesar 1.992. Nilai ini lebih besar dari t tabel $(1.992>1,984)$. Dengan demikian pengujian menunjukkan Ha diterima atau Ho ditolak. Hasil ini memperlihatkan bahwa variabel Responsvieness berpengaruh secara signifikan terhadap kepuasan pelanggan.

d. Variabel Assurance. Varibel Assurance memiliki nilai t hitung sebesar 6.576. Nilai ini lebih besar dari $\mathrm{t}$ tabel $(6.576>1,984)$. Dengan demikian pengujian menunjukkan Ha diterima dan Ho ditolak. Hasil ini memperlihatkan bahwa variabel Assurance berpengaruh secara signifikan terhadap kepuasan pelanggan.

e. Variabel Empathy. Varibel Empathy memiliki nilai t hitung sebesar -7.259. Nilai ini lebih kecil dari t tabel $(-7.259<1,984)$. Dengan demikian pengujian menunjukkan Ha ditolak atau Ho diterima. Hasil ini memperlihatkan bahwa Variabel Empathy memilik pengaruh negatif terhadap kepuasan pelanggan.

\section{Kesimpulan}

1. Regresi linear berganda $Y=4.721+0,207 X 1+0,222 \mathrm{X} 2+0,182 \mathrm{X} 3+0,350 \mathrm{X} 4$ 0,394 X5 Hasil penelitian menunjukkan bahwa dari keseluruhan variabel kualitas pelayanan yang terdiri dari; Tangible X1, variabel Assurance X2, variabel Responsiveness X3, dan variabel Reliability X4 secara parsial mempunyai pengaruh signifikan terhadap kepuasan pelanggan (Y) hanya Empathy X5 saja yang tidak mempunyai pengaruh signifikan terhadap kepuasan pelanggan (Y).

2. F hitung sebesar 27.221 sedangkan hasil $F$ tabel 2,31. Hal ini berarti Fhitung > Ftabel $(27.221>2,31)$ signifikan. Perhitungan tersebut menunjukkan bahwa kualitas jasa yang terdiri atas tangible, reliability, responsiveness, assurance, dan empathy secara bersama-sama mempunyai pengaruh yang positif dan signifikan terhadap variabel kepuasan pelanggan. Hasil uji t dapat diketahui hasil koefisien $\mathrm{t}$ hitung menunjukkan bahwa Varibel Tangibles memiliki nilai $\mathrm{t}$ hitung sebesar 3.384. Nilai ini lebih besar dari t tabel $(3.384>1,986)$. Variabel Reliability memiliki nilai $\mathrm{t}$ hitung sebesar 3.058. Nilai ini lebih besar dari $\mathrm{t}$ tabel (3.058 > 1,986). Varibel Responsiveness memiliki nilai t hitung sebesar 1.992. Nilai ini lebih besar dari t tabel $(1.992>1,986)$. Variabel Assurance memiliki nilai t hitung sebesar 6.576. Nilai ini lebih besar dari t tabel $(6.576>1,986)$. Varibel Empathy memiliki nilai t hitung sebesar -7.259. Nilai ini lebih kecil dari t tabel $(-7.259<$ 1,986).

3. Hasil uji multikolinearitas dapat dikatakan tidak terjadi multikolinearitas, dengan demikian analisis regresi dapat dilanjutkan. Uji Heterokedastisitas dapat diketahui bahwa nilai signifikansi untuk Tangible sebesar 0,477, Reliability sebesar 0,437, Responsiveness sebesar 0,297, Assurance sebesar 0,554 dan Emphaty sebesar 0,446. Karena signifikansi lebih dari 0,05, maka dapat disimpulkan bahwa pada model regresi tidak ada masalah Heterokedastisitas. Uji autokorelasi. dapat 
diketahui nilai DW yang dihasilkan dari model regresi adalah 1.902. Sedangkan dari tabel DW dengan signifikansi 0,05 dan jumlah data $(\mathrm{n})=100$, seta $\mathrm{k}=5(\mathrm{k}$ adalah jumlah variabel independen) diperoleh nilai dL sebesar 1,5710 dan dU sebesar 1,7804 (lihat lampiran). Karena nilai DW (1.902) berada pada daerah > dl, maka menghasilkan kesimpulan berarti terdapat autokorelasi.

\section{Saran}

1. Bagi PT. Pelindo II Cabang Bengkulu, dianjurkan untuk terus menjaga dan mempertahankan variabel Assurance Dan meningkatkan veriabel-veriabel yang belum dominan, khususnya variabel Empathy.

2. Penelitian ini sekiranya dapat membantu untuk dijadikan acuan oleh perusahaan dalam mengambil kebijakan, khususnya mengenai masalah faktor-faktor yang mempengaruhi kualitas pelayanan terhadap kepuasan pelanggan

3. Dapat dimanfaatkan sebagai rujukan dalam melakukan penelitian berikutnya terutama mengenai faktor-faktor yang mempengaruhi kualitas pelayanan terhadap kepuasan pelanggan dengan mengembangkan variabel yang lebih luas.

\section{DAFTAR PUSTAKA}

Berry,L., Zeithaml,V., Parasuraman,A., (2008)'The Service-Quality Puzzle',Business Horizons

Hermawan Kartajaya, Yuswohady, Dewi Madyani, Bembi Dwi Indrio. 2003. Marketing in Venus, Cetakan kedua, Penerbit PT. Gramedia Pustaka Utama, Jakarta.

Indonesiaport, 2013. news.(Online), (hhtp://indonesiaport.co.id diakses 20 Juni 2013 pukul $19.30 \mathrm{Wib}$ )

Kaplan, Robert M. and Saccuzo, Dennis. 2000. Psychological Testing, Principles, Applcations, and Issues, Brool/Cole Publishing Company, a division of Wadsworth, Inc.

Kotler, Philip, AB Susanto. 2002. Manajemen Pemasaran di Indonesia, Buku 2, Penerbit Salemba Empat, Jakarta.

Rangkuti, Freddy, 2000. Riset Pemasaran, PT. Gramedia Pustaka Utama,Jakarta.

Rangkuti, Fredy. 2002. Teknik Mengukur Dan Strategi Meningkatkan Kepuasan Pelanggan Dan Analisis Kasus PLN-JP. PT. Gramedia Pustaka Utama, Jakarta.

Solimun, 2002. Multivariate Analysis Structural Equation Modelling (SEM), Lisrel dan Amos: Aplikasi di Manajemen, Ekonomi Pembangunan, Psikologi, Sosial, Kedokteran dan Agrokompleks. Universitas Negeri Malang, Malang.

Sudrajat, 2000, Dasar-dasar penelitian Ilmiah. Pustaka Setia. Bandung

Sugiyono,2008. Statistik Untuk Penelitian.Bandung : Alfabeta.

Tjiptono, Fandy, 2000. Manajemen Jasa, Edisi Kedua, Andy Offset. Jakarta

Tjiptono, Fandy. 2002. Strategi Pemasaran. Edisi Kedua. Cetakan Keenam. Penerbit. Andy. Yogyakarta.

Wikipedia, 2013. Perdagangan Bebas.(Online), (http://id.wikipedia.org diakses 20 Juni 2013 pukul $19.30 \mathrm{Wib})$ 